\title{
Patterns of coral spawning at Akajima Island, Okinawa, Japan
}

\author{
T. Hayashibara ${ }^{1}$, K. Shimoike ${ }^{1}$, T. Kimura ${ }^{1}$, S. Hosaka ${ }^{1}$, A. Heyward ${ }^{2}$, P. Harrison ${ }^{3}$, \\ K. Kudo ${ }^{4}$ M. Omori ${ }^{5}$ \\ ${ }^{1}$ Akajima Marine Science Laboratory, 179 Aka, Zamami-son, Okinawa 901-33, Japan \\ ${ }^{2}$ Department of Obstetrics, School of Medicine, University of Adelaide, GPO Box 498, Adelaide, SA 5045, Australia \\ ${ }^{3}$ Faculty of Resource Science \& Management, University of New England, Northern Rivers, PO Box 157, Lismore, NSW 2480, Australia \\ 4Japan Marine Science and Technology Center, Natsushima-cho, Yokosuka 238, Japan \\ ${ }^{5}$ Akajima Marine Science Laboratory and Department of Aquatic Biosciences, Tokyo University of Fisheries, 4-5-7 Konan, \\ Minato-ku, Tokyo 108, Japan
}

\begin{abstract}
Field observations of spawning behavior of scleractinian corals around Akajima Island were carried out from late spring to summer in 1989, 1990 and 1991. Investigations focused on the degree of spawning synchrony among Acropora spp. and its relation to fluctuations in environmental factors. Eighty-five species, representing 27 genera and 10 families of scleractinian corals, were observed to spawn from May to early September during the 3 years. Spawning of most Acropora spp. took place synchronously but timing varied between the 3rd night before to the 7 th night after full moon in May and/or June. Non-Acropora species spawned mainly from the 2nd to the 8th night after full moon from June to August. The relationship between date of spawning and lunar phase was not clear, but other environmental stimuli such as marked changes of temperature, salinity and current velocity might trigger mass synchronous spawning among the Acropora.
\end{abstract}

\section{INTRODUCTION}

The literature on sexual reproduction of scleractinian corals greatly increased during the 1980s, highlighted by key discoveries such as the multispecific broadcast spawning of corals on the Great Barrier Reef (reviewed by Harrison \& Wallace 1990). Richmond \& Hunter (1990) reviewed reproduction of corals in the Caribbean, the Tropical Pacific (Great Barrier Reef, Central Pacific, Hawaii and Okinawa) and the Red Sea, and noted that while marked synchronous spawning occured in many species during a brief period in the Great Barrier Reef, asynchronous spawning among and within species has been observed in some other locations.

With regard to factors affecting the spawning of corals, Oliver et al. (1988) emphasized the importance of distinguishing between ultimate factors which are evolutionary selective pressures responsible for the development and persistence of a phenomenon, and proxi- mate cues which provide reliable timing indicators to synchronize spawning. It has been suggested that coral spawning is synchronized by: the annual sea temperature cycle acting as a seasonal cue; the lunar phase (nocturnal illumination) acting as a fine tuner for a particular night(s); and the onset of darkness and tidal regimes serving as a forcing function which determines the actual timing of spawning. In this way the release of gametes takes place after nightfall following the first full moon (or new moon) subsequent to the maturation of gonads (Babcock et al. 1986, Hunter 1988, Harrison \& Wallace 1990, Richmond \& Hunter 1990).

The present paper deals with reproduction and spawning behavior of scleractinian corals at Akajima Island, Okinawa, Japan. This work is part of an ongoing research program at the Akajima Marine Science Laboratory for conservation of coral reefs in the Kerama Islands. After investigation of reproductive patterns of the corals over 3 yr, we propose possible causative factors for the synchrony within and among species. 


\section{MATERIALS AND METHODS}

Study sites. Akajima Island is one of the Kerama Island group, $30 \mathrm{~km}$ west of Okinawa Island in the Nansei Island Chain, southern Japan (Fig. 1). Coral spawning was studied at 5 sites on fringing reefs around Akajima Island (Fig. 1). Site 1 extended from the outer reef flat to the upper part of the reef slope on the east coast; Site 2 lay from the inner to the outer reef flat on the western coast; Site 3 was situated in the middle part of a small bay; Site 4 was set on an exposed reef of the north coast; Site 5 was situated in the Aka fishermen's harbour.

The tidal range at Akajima is approximately $2 \mathrm{~m}$. All sites were in shallow locations (less than $5 \mathrm{~m}$, mostly in 0.5 to $2 \mathrm{~m}$ depth at low tide), located within $250 \mathrm{~m}$ of the shore.

In 1989 , a preliminary study was performed at Sites $1,3,4 \& 5$, and a more extensive study was made in 1990 at Sites $1,3 \& 5$. In 1991, 2 replicate $7 \times 7 \mathrm{~m}$ quadrats were established at each of Sites 1 \& 2 to observe spawning, particularly of corals in the genus Acropora, in detail. Coral coverage at Site 1 was over $60 \%$, of which Acropora species provided $80 \%$ of the total coral coverage (T. Hayashibara, K. Shimoike \& T. Kimura unpubl.). The other sites had similar percentages of coral coverage.

Spawning abservations. Maturation of coral gonads was observed from about $1 \mathrm{wk}$ prior to the full moon in May, June and July in 1989, and from May to August in 1990. During these periods, eggs become obviously pigmented and observations of sperm under a high magnification microscope showed that sperm heads were condensing. Colonies of different species with mature gonads were tagged and a portion of each colony was transported to the laboratory aquaria for observation. Field observations were made at night when weather permitted, from full moon to new moon.

In April and May, 1991, in each quadrat, all the colonies of Acropora which were large enough for identification to species level were tagged and the color of their gonads recorded. Field observations from 20:30 to 22:30 h (local time) were carried out almost every night from 29 April (full moon) to 12 July 1991 (2nd night after the new moon). Observations were continued around the full moon of each month until early September. Colonies of some Acropora species which did not appear in the quadrats but occurred around the sites were also tagged for additional observations, and spawning of non-Acropora species around the sites was recorded. Besides direct observations in the field or from aquaria, spawning behavior was detected indirectly from the disappearance of gonads between sequential samples from tagged colonies in the field.

Record of environmental factors. In order to examine the relationships between synchronous spawning of Acropora species and environmental factors, continuous measurements of seawater temperature with RMT memory type thermometers and seawater level by means of RMD memory type bathymeters were made from mid-May to mid-June 1991. The thermometers were set at the outer reef flat and upper reef slope of Site 1 and the outer reef flat of Site 2, while the bathymeters were set at the outer reef flat

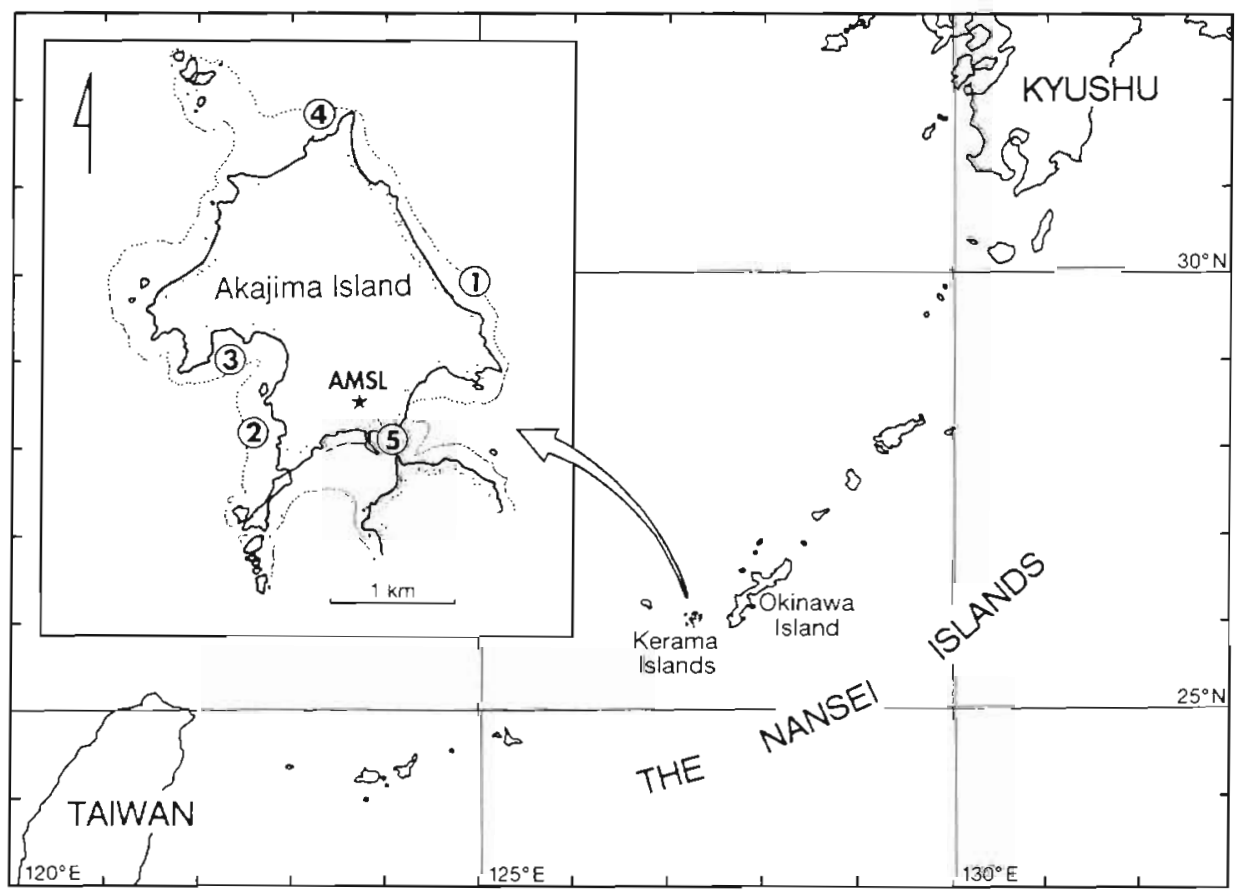

Fig. 1. Location of Akajima Island, Japan, and study sites 1 to 5. Location of Akajima Marine Science Laboratory (AMSL) is also indicated. Broken line indicates the extent of the fringing reef 
of Sites 1 \& 2. In addition, current vector and salinity were recorded continuously using electromagnetic current meter $\mathrm{ACM}-8 \mathrm{M}$ and salinometer UCT-16000 from mid-May to early June 1991 at the upper reef slope of Site 1 . All recording devices were set at 1.3 to $2.6 \mathrm{~m}$ depth below mean sea level.

During field observations in 1990 and 1991, seawater temperature was also measured by Scuba divers. Daily records of the surface seawater temperature were taken at the Aka fishermen's harbour (Site 5) during the study period. Daily precipitation was recorded by the weather station in Tokashiki Island, one of the Kerama Island group.

\section{RESULTS}

A total of 85 species from 26 genera and 10 families of scleractinian corals were observed to release gametes from 1989 to 1991 (Tables 1 \& 2). Seventyseven species were hermaphroditic, and 8 species were gonochoric, including Galaxea fascicularis which is a functional gonochoric species (Harrison 1988). Except for 9 species in which spawning was detected indirectly, all of the hermaphroditic species exhibited broadcast spawning and released gametes as egg and sperm bundles. Only data from field observations were used for analysis of spawning behaviour of Acropora, as the timing of the spawning was not consistent even from the same colony between in situ and aquaria observations.

In 1991, due to a typhoon about $1 \mathrm{wk}$ before the spawning period, many tags were lost from colonies and we could record the spawning of only 23 to $72 \%$ of the previously tagged colonies in the 4 quadrats.

In 1989, the spawning of 12 species of Acropora was inferred to occur during the period from 23 to 26 May, the 3 rd to the 6 th night after the full moon, based on disappearance of the gonads between sequential samples and appearance of the gametes at the sea surface
Table 1 Records of Acropora species spawning in the field during 1989-1991: from May to July 1989; from May to August 1990; and from May to September 1991 'More than 10 colonies observed to spawn synchronously; -? -: spawning inferred to occur during the period by sequentral samples more than $2 \mathrm{~d}$ apart

\begin{tabular}{|c|c|c|c|c|c|c|}
\hline \multirow[t]{2}{*}{ Species } & \multirow[t]{2}{*}{ Year } & \multirow{2}{*}{$\begin{array}{c}\text { No. of } \\
\text { colonies } \\
\text { observed }\end{array}$} & \multicolumn{4}{|c|}{$\begin{array}{l}\text { Spawning dates: nights before (-) } \\
\text { or after full moon of }\end{array}$} \\
\hline & & & May & June & July & August \\
\hline Acropora anthocercis & s 91 & 3 & & & 5 & $5-?-7$ \\
\hline A. aspera & 89 & 2 & $3-?-6$ & 0 & & \\
\hline \multirow[t]{3}{*}{ A. cytherea } & 91 & 8 & $-2,-1$ & & & \\
\hline & 90 & 2 & -3 & & & \\
\hline & 89 & 2 & $3-?-6$ & & & \\
\hline A. danai & 90 & 1 & & 6 & & \\
\hline \multirow[t]{3}{*}{ A. digitifera } & 91 & 93 & $-2^{*},-1^{*}$ & 2 & & \\
\hline & 90 & 2 & & -3 & & \\
\hline & 89 & 1 & & 0 & & \\
\hline A. divaricata & 91 & 5 & & & $10-?-27$ & $12-?-15$ \\
\hline A. donei & 91 & 5 & & 4 & & \\
\hline A. exquisita? & 89 & 1 & $3-?-6$ & & & \\
\hline \multirow[t]{2}{*}{ A. florida } & 91 & 4 & & 2,3 & 4 & \\
\hline & 90 & 1 & & 12 & & \\
\hline \multirow[t]{3}{*}{ A. formosa } & 91 & 17 & $-2,-1$ & & & \\
\hline & 90 & 5 & 7 & $-3,1$ & & \\
\hline & 89 & 2 & $3-?-6$ & 0 & & \\
\hline \multirow{2}{*}{ A. gernmifera } & 91 & 16 & $-2,-1 \cdot$ & 2 & & \\
\hline & 90 & 4 & & -3 & & \\
\hline A. grandis & 89 & 3 & $3-?-6$ & 0 & & \\
\hline A. humilis & 91 & 2 & & & 4,5 & \\
\hline \multirow[t]{3}{*}{ A. hyacinthus } & 91 & 50 & $-2,-1 \cdot$ & 3 & & \\
\hline & 90 & 15 & 6,7 & $-3,13$ & & \\
\hline & 89 & 8 & $3-?-6$ & 0 & & \\
\hline A. latistella & 91 & 4 & & & & $?-10,12-?-15$ \\
\hline \multirow[t]{2}{*}{ A. longicyathus } & 91 & 1 & -1 & & & \\
\hline & 90 & 1 & $-2-?-18$ & & & \\
\hline A. loripes & 91 & 1 & -2 & & & \\
\hline A. microclados & 91 & 1 & & & & 6 \\
\hline \multirow[t]{2}{*}{ A. microphthalma } & 91 & 1 & -1 & & & \\
\hline & 90 & 3 & & $-3,6,13$ & & \\
\hline A. millepora & 90 & 1 & & -1 & & \\
\hline A. monticulosa & 91 & 10 & $-2,-1$ & & & \\
\hline \multirow[t]{3}{*}{ A. nasuta } & 91 & 130 & $-2^{\bullet},-1^{\circ}$ & & & \\
\hline & 90 & 12 & & $-3,-1,6$ & 13 & \\
\hline & 89 & 5 & $3-?-6$ & 0 & & \\
\hline \multirow[t]{3}{*}{ A. nobilis } & 91 & 18 & $-2,-1 \cdot$ & 3 & & \\
\hline & 90 & 5 & 7 & $-3,1,13$ & & \\
\hline & 89 & 2 & $3-?-6$ & 0 & & \\
\hline \multirow[t]{2}{*}{ A. pulchra } & 90 & 1 & & $1-?-5$ & & \\
\hline & 89 & 2 & & 0 & & \\
\hline \multirow[t]{2}{*}{ A. robusta } & 91 & 3 & -1 & & & \\
\hline & 89 & 3 & $3-?-6$ & & & \\
\hline A. samoensis & 91 & 2 & & & 5 & $5-?-6$ \\
\hline \multirow[t]{2}{*}{ A. tenuis } & 91 & 5 & $-2,-1$ & & & \\
\hline & 89 & 1 & $3-?-6$ & & & \\
\hline \multirow[t]{2}{*}{ A. valenciennesi } & 91 & 2 & -1 & & & \\
\hline & 89 & 2 & $3-?-6$ & 0 & & \\
\hline A. valida & 91 & 8 & & & 5. $13-?-27$ & $5,5-?-6$ \\
\hline & 90 & 2 & & 6 & & \\
\hline & 89 & 1 & & 0 & & \\
\hline A. verweyi? & 91 & 1 & & & & $10-?-22$ \\
\hline A. sp. 1 & 91 & 10 & & & $5^{\circ}$ & \\
\hline A. sp. 2 & 91 & 7 & -1 & & & \\
\hline
\end{tabular}


Table 2. Records of non-Acropora species spawning from May to July 1989, from May to August 1990, and from May to September 1991. a: Observations in the field; $\mathrm{b}$ : sequential field samples more than $2 \mathrm{~d}_{\text {apart }} \mathrm{c}$ : aquaria observations; ${ }^{\circ}$ more than 10 colonies observed to spawn synchronously; -?-: spawning inferred to occur during the period

\begin{tabular}{|c|c|c|c|c|c|c|c|}
\hline \multirow{2}{*}{\multicolumn{2}{|c|}{ Species }} & \multirow[t]{2}{*}{ Year } & \multirow{2}{*}{$\begin{array}{l}\text { No. of colonies } \\
\text { observed \& type } \\
\text { of observations }\end{array}$} & \multicolumn{4}{|c|}{ Spawning dates: nights after full moon of } \\
\hline & & & & May & June & July & August \\
\hline \multicolumn{8}{|l|}{ ACROPORIDAE } \\
\hline \multirow{2}{*}{\multicolumn{2}{|c|}{ Astreopora myriophthalma }} & 91 & $1 \mathrm{a}$ & & & 8 & \\
\hline & & 90 & $1 \mathrm{~b}$ & & 13 & & \\
\hline \multirow{3}{*}{\multicolumn{2}{|c|}{ Montipora digitata }} & 91 & $>10 a$ & $3^{\cdot}$ & & & \\
\hline & & 90 & $1 \mathrm{a}$ & & 3 & & \\
\hline & & 89 & $1 \mathrm{c}$ & & $1,2,3$ & & \\
\hline M. aequituberculata & & 91 & $>10 \mathrm{a}$ & $2,3^{\circ}$ & & & \\
\hline \multirow{2}{*}{\multicolumn{2}{|c|}{$M$. informis }} & 91 & $>10 \mathrm{a}$ & $3: 4$ & & & 2 \\
\hline & & 90 & $1 \mathrm{a}$ & & 3 & & \\
\hline \multirow{2}{*}{\multicolumn{2}{|c|}{ M. turgescens }} & 91 & $1 \mathrm{a}$ & & & & 7 \\
\hline & & 90 & $1 \mathrm{a}$ & & 3 & & \\
\hline M. floweri? & & 91 & $1 \mathrm{a}$ & & & 6 & \\
\hline M. venosa & & 91 & $2 a$ & & & 6,7 & \\
\hline$M$. efflorescens & & 91 & $1 \mathrm{a}$ & & & & 7 \\
\hline \multicolumn{8}{|l|}{ PORITIDAE } \\
\hline \multirow[t]{2}{*}{ Porites lutea } & $\sigma^{\prime \prime} \rho$ & 91 & $3 a$ & & 6 & & \\
\hline & $\sigma^{3}$ & 90 & $5 a$ & & & 5 & \\
\hline \multicolumn{8}{|l|}{ AGARICIIDAE } \\
\hline Pachyseris speciosa & 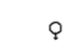 & 90 & $2 b, c$ & & & & 7 \\
\hline \multicolumn{8}{|l|}{ FUNGIIDAE } \\
\hline Fungia repanda & 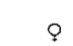 & 90 & $1 \mathrm{c}$ & & & 3 & \\
\hline \multirow{2}{*}{\multicolumn{8}{|c|}{$\begin{array}{l}\text { Sandalolitha robusta } \\
\text { OCULINIDAE }\end{array}$}} \\
\hline & & & & & & & \\
\hline \multirow[t]{3}{*}{ Galaxea fascicularis } & q & 91 & $4 a$ & & & 5 & \\
\hline & $\stackrel{1}{9}$ & 90 & $1 \mathrm{a}, 1 \mathrm{~b}$ & & 7 & $12-?-28$ & \\
\hline & \% & 89 & $2 c$ & & 8 & 9 & \\
\hline \multicolumn{8}{|l|}{ PECTINIIDAE } \\
\hline \multicolumn{2}{|l|}{ Echinophyllia aspera } & 90 & $1 \mathrm{c}$ & & & 3 & \\
\hline Oxypora lacera & & 89 & 1a & & 9 & & \\
\hline Pectinia lactuca & & 90 & $1 . b$ & & & $14-?-21$ & \\
\hline MUSSIDAE & & & & & & & \\
\hline Lobophyllia corymbosa & & 89 & $1 \mathrm{a}$ & & 3 & & \\
\hline MERULINIDAE & & & & & & & \\
\hline Hydnophora ngida & & 91 & $>10 \mathrm{a}$ & $7^{\cdot}$ & $6^{\circ}$ & & \\
\hline H. exesa & & 91 & $1 \mathrm{a}$ & & & 8 & \\
\hline Merulina ampliata & & 91 & $3 a$ & & & 5,7 & \\
\hline & & 90 & $2 a, 1 b, 3 c$ & & & $6,12-?-28$ & 5,6 \\
\hline M. scabricula & & 90 & $1 \mathrm{c}$ & & & 5,6 & \\
\hline FAVIIDAE & & & & & & & \\
\hline Caulastrea furcata & & 91 & $4 \mathrm{a}, 1 \mathrm{c}$ & & 2,3 & & \\
\hline Favia pallida & & 91 & $2 a$ & & & 6 & \\
\hline & & 90 & $4 b, 6 c$ & & $3,4-2-7,7$ & 3 & $-2-?-6$ \\
\hline & & 89 & $1 a, 1 b$ & & 3 & $-5-?-3$ & \\
\hline F. speciosa & & 90 & $1 \mathrm{~b}$ & & $-3-?-5$ & & \\
\hline & & 89 & $1 \mathrm{a}$ & & 6 & & \\
\hline F. lizardensis? & & 90 & $1 \mathrm{~b}$ & & $8-?-9$ & & \\
\hline F. matthaii & & 91 & $1 \mathrm{a}$ & & & 6 & \\
\hline & & 90 & $1 \mathrm{~b}$ & & $4-?-5$ & & \\
\hline F. favus & & 91 & $>10 a, 1 c$ & & & $6,7^{\circ}$ & 5 \\
\hline & & 90 & $1 \mathrm{a}, 4 \mathrm{c}$ & & & & $5,7,8$ \\
\hline & & 89 & $1 \mathrm{c}$ & & & 7 & \\
\hline F. stelligera & & 90 & $1 \mathrm{c}, 1 \mathrm{~b}$ & & & 6 & 7 \\
\hline F. veroni & & 90 & $1 \mathrm{c}$ & & & & 6 \\
\hline Barabattoia amicorum & & 91 & $1 a$ & & & 6 & \\
\hline
\end{tabular}


Table 2 (continued)

\begin{tabular}{|c|c|c|c|c|c|c|c|}
\hline \multirow[t]{2}{*}{ Species } & & \multirow[t]{2}{*}{ Year } & \multirow{2}{*}{$\begin{array}{l}\text { No. of colonies } \\
\text { observed \& type } \\
\text { of observations }\end{array}$} & \multicolumn{4}{|c|}{ Spawning dates: nights after full moon of } \\
\hline & & & & May & June & July & August \\
\hline \multirow{2}{*}{\multicolumn{2}{|c|}{ Favites halicora }} & 91 & $2 \mathrm{a}, 1 \mathrm{c}$ & & 2 & 6 & \\
\hline & & 90 & $2 c$ & & 3 & & 8 \\
\hline \multirow{2}{*}{\multicolumn{2}{|c|}{ F. abdita }} & 91 & $3 a$ & & & 6 & \\
\hline & & 90 & $2 a$ & & & & 6 \\
\hline \multirow{2}{*}{\multicolumn{2}{|c|}{ F. flexuosa }} & 91 & $1 \mathrm{a}$ & & & 6 & \\
\hline & & 90 & $1 \mathrm{a}, 1 \mathrm{c}$ & & & & 6,7 \\
\hline \multicolumn{2}{|l|}{ F. chinensis } & 89 & $1 \mathrm{c}$ & & $6,7,8$ & & \\
\hline \multicolumn{2}{|l|}{ Goniastrea retiformis } & 91 & $>10 a$ & & 2 & $6 \cdot 7$ & 7 \\
\hline \multirow{2}{*}{\multicolumn{2}{|c|}{ G. pectinata }} & 91 & $1 c_{1}>10 \mathrm{a}$ & & & $5,6,7$ & $5,6: 7$ \\
\hline & & 90 & $5 a$ & & & & 6,7 \\
\hline G. aspera & & 89 & $2 c$ & & $5,6,7$ & $5,6,7$ & \\
\hline \multirow{3}{*}{\multicolumn{2}{|c|}{ Platygyra pini }} & 91 & $1 \mathrm{c}, 1 \mathrm{a}$ & & 1,2 & & \\
\hline & & 90 & $1 \mathrm{c}, 2 \mathrm{~b}$ & & $1,4-\xi-5$ & & \\
\hline & & 89 & $1 \mathrm{C}$ & & 3,4 & & \\
\hline \multicolumn{2}{|l|}{ P. ryukyuensis } & 91 & $2 \mathrm{a}$ & & & 5 & 7 \\
\hline \multicolumn{2}{|l|}{$P$ sinensis } & 91 & $5 a$ & & 2 & 5,8 & \\
\hline \multirow{2}{*}{\multicolumn{2}{|c|}{ P. daedalea }} & 91 & $1 \mathrm{a}$ & & & 8 & \\
\hline & & 89 & $1 \mathrm{a}$ & & 7 & & \\
\hline \multicolumn{2}{|l|}{ P. lamellina } & 90 & $1 \mathrm{a}$ & & 3 & & \\
\hline \multicolumn{2}{|l|}{$P$. contorta } & 91 & $1 \mathrm{a}$ & & & 7 & \\
\hline \multirow{2}{*}{\multicolumn{2}{|c|}{ Montastrea curta }} & 91 & $1 c$ & & & & 5 \\
\hline & & 90 & $1 c$ & & & 12 & \\
\hline \multirow{2}{*}{\multicolumn{2}{|c|}{ M. magnistellata }} & 91 & $3 a$ & & & $5,6,8$ & \\
\hline & & 90 & $1 c$ & & & & 3 \\
\hline \multirow{2}{*}{\multicolumn{2}{|c|}{ M. valenciennesi }} & 91 & $1 \mathrm{a}$ & & & & 6 \\
\hline & & 90 & $2 b$ & & & & $0-?-6$ \\
\hline Diploastrea heliopora & \& & 90 & $1 b$ & & $5-?-6$ & & \\
\hline Leptastrea purpurea & \% & 90 & $1 \mathrm{c}$ & & & 2 & \\
\hline \multirow{2}{*}{\multicolumn{2}{|c|}{ Cyphastrea chalcidicum }} & 91 & $1 \mathrm{a}$ & & 2 & & \\
\hline & & 90 & $3 a$ & & 3 & & \\
\hline \multicolumn{2}{|l|}{ C. serailia } & 91 & $1 \mathrm{a}$ & & & 5 & \\
\hline \multicolumn{2}{|l|}{ Echinopora gemmacea } & 91 & $1 \mathrm{a}$ & & 5 & & \\
\hline \multicolumn{2}{|l|}{ E. pacificus } & 91 & $1 \mathrm{a}$ & & 2 & & \\
\hline \multicolumn{8}{|l|}{ CARYOPHYLLIIDAE } \\
\hline Euphyllia divisa & 0 & 90 & $1 \mathrm{c}$ & & & & -1 \\
\hline
\end{tabular}

(Table 1). Ten species of Acropora spawned on 19 June, the night of the full moon (Table 1). In addition, spawning of 11 species belonging to genera other than Acropora was recorded in June and July (Table 2).

In 1990, coral spawning was first observed on 16 May, the 6th night after the full moon. The final spawning was recorded on 13 August, the 7 th night after the full moon of that month. However, a few colonies of Galaxea fascicularis and Astreopora myriophthalma still contained mature gonads even at the end of August. Large-scale synchronous spawning of Acropora species occurred on 17 May, the 7 th night after the full moon, and on 5 June, the 3rd night before the full moon (Table 1). Species of corals in the family Faviidae and some other species showed synchronous spawning on 11 June, the 3rd night after the full moon and on 12 and 13 August, the 6 th and 7 th nights after the full moon (Table 2).
In 1991, synchronous spawning of more than 10 species of Acropora occurred at Site 1 on 26 and 27 May, 1 and 2 nights immediately prior to the full moon; however, the spawning at Site 2 was on 27 May only (Table 1). Three species of Acropora spawned synchronously on 29 June, the 2nd night after the full moon, and 4 species of Acropora did so on 1 August, the 5 th night after the full moon (Table 1). On 31 May, the 3rd night after the full moon, 3 species of Montipora spawned synchronously (Table 2). More than 10 colonies of Hydnophora rigida showed synchronous spawning twice on both 4 June and 3 July, the 7 th and 6 th night after the full moon, respectively (Table 2 ). Synchronous spawnings of other species, including a majority of Faviidae species, occurred on 29 June, 1 to 4 and 31 August, the 2nd night, the 5th to the 8 th night and 6th night after the full moon, respectively (Table 2). 


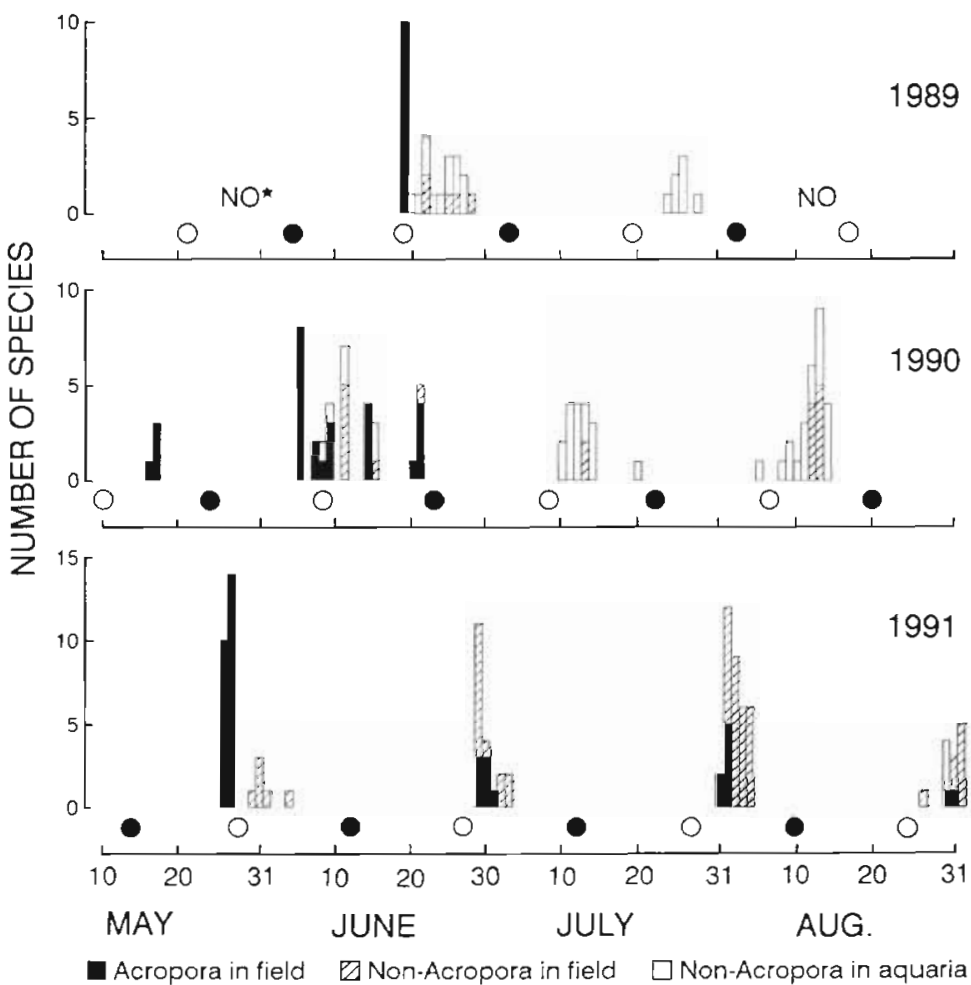

Fig. 2. Spawning of coral species for which the exact date could be determined in Akajima, 1989-1991. NO = no observation. ${ }^{\star} 12$ species of Acropora were inferred to spawn in the field during 23 to 26 May. Moon phase is indicaled by open circles (full moon) and solid circles (new moon)

Fig. 2 summarizes all spawning records from 1989 to 1991 for which the exact spawning date could be determined. From these observations, spawning of scleractinian corals took place between May and September. The number of coral species spawning showed peaks in late May/June and August in 1990 and 1991 .

More than $95 \%$ of Acropora colonies spawned over an $11 \mathrm{~d}$ period, from the $3 \mathrm{rd}$ night before to the 7 th night after the full moon, whilst other genera spawned mostly from the 2 nd to the 8 th nights after the full moon (Fig. 2, Table 3).

Coral spawnings were mostly observed from 1.5 to $4 \mathrm{~h}$ after sunset. Acropora tenuis and $A$. donei, however, were inferred to spawn between 18:00 and 20:30 h on 27 May (sunset was 19:20 h) and 1 July (sunset was 19:30 h) 1991. One Fungia repanda released eggs at 02:00 $\mathrm{h}$ and a male and a female of Sandalolitha robusta held in separate aquaria released gametes synchronously at $00: 15 \mathrm{~h}$ on $12 \mathrm{July}$ 1990.

In Akajima, spring tides occur $1 \mathrm{~d}$ before to $2 \mathrm{~d}$ after the full moon and new moon, and neap tides occur 6 to 9 or 7 to $10 \mathrm{~d}$ after the full moon and new moon, respectively. On the day of the full moon, high tides occurred at about 06:30 and 20:00 h consistently during May to August, 1990 and 1991. Most of the spawnings took place around slack water of the high tide; however, the synchronous spawning of Acropora spp. on 26 and 27 May 1991 occurred coincident with strong currents on the falling tide (Fig. 3).

The annual seawater temperature variation at Site 5 is shown in Fig. 4. Temperature rose rapidly between May and June and then became stable from July to early September. Thus, synchronous spawning of Acropora took place during the rapid temperature rise period, whereas the spawning of Favidae occurred mainly in the stable temperature period each year.

Marked changes of temperature were observed on the dates around synchronous spawning of Acropora spp. For example, according to diver's records at Site 1, seawater temperature varied between 22.9 and $23.9^{\circ} \mathrm{C}$ from 10 to 15 May 1990 , but rose to $25.0^{\circ} \mathrm{C}$ on $16 \mathrm{May}$, when a few colonies of A. hyacinthus spawned. It rose further to $25.5^{\circ} \mathrm{C}$ on $17 \mathrm{May}$, when synchronous spawning occurred. At Site 5 , the temperature declinedfrom 26.7 to $24.7^{\circ} \mathrm{C}$ during the previous $19 \mathrm{~h}$ on 5 June 1990, on which the synchronous spawning was again observed (Fig. 5).

In 1991, marked changes in seawater temperature were also recorded on 26 and 27 May when synchronous spawning occurred at Site 1 . At the upper reef slope of Site 1, 3 distinct peaks of temperature were recorded, correlated to the high tide (Figs. $6 \& 7$ ). A drop in salinity and marked strong currents were also recorded, and closely coincided with the temperature peaks (Fig. 6). At the outer reef flat of Site 1, the tem-

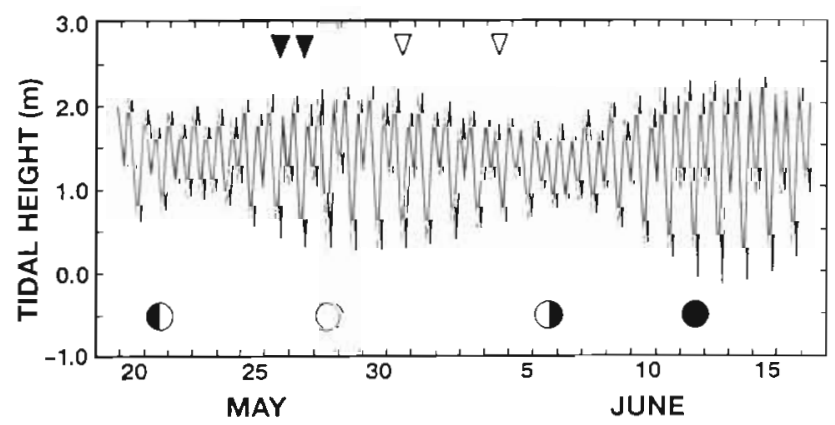

Fig. 3. Fluctuation of tidal height from 20 May to 17 June 1991 at Akajima. Dates of synchronous spawning of Acropora spp. $(\boldsymbol{\nabla})$ and non-Acropora species $(\nabla)$ are indicated. Moon phase is also indicated 


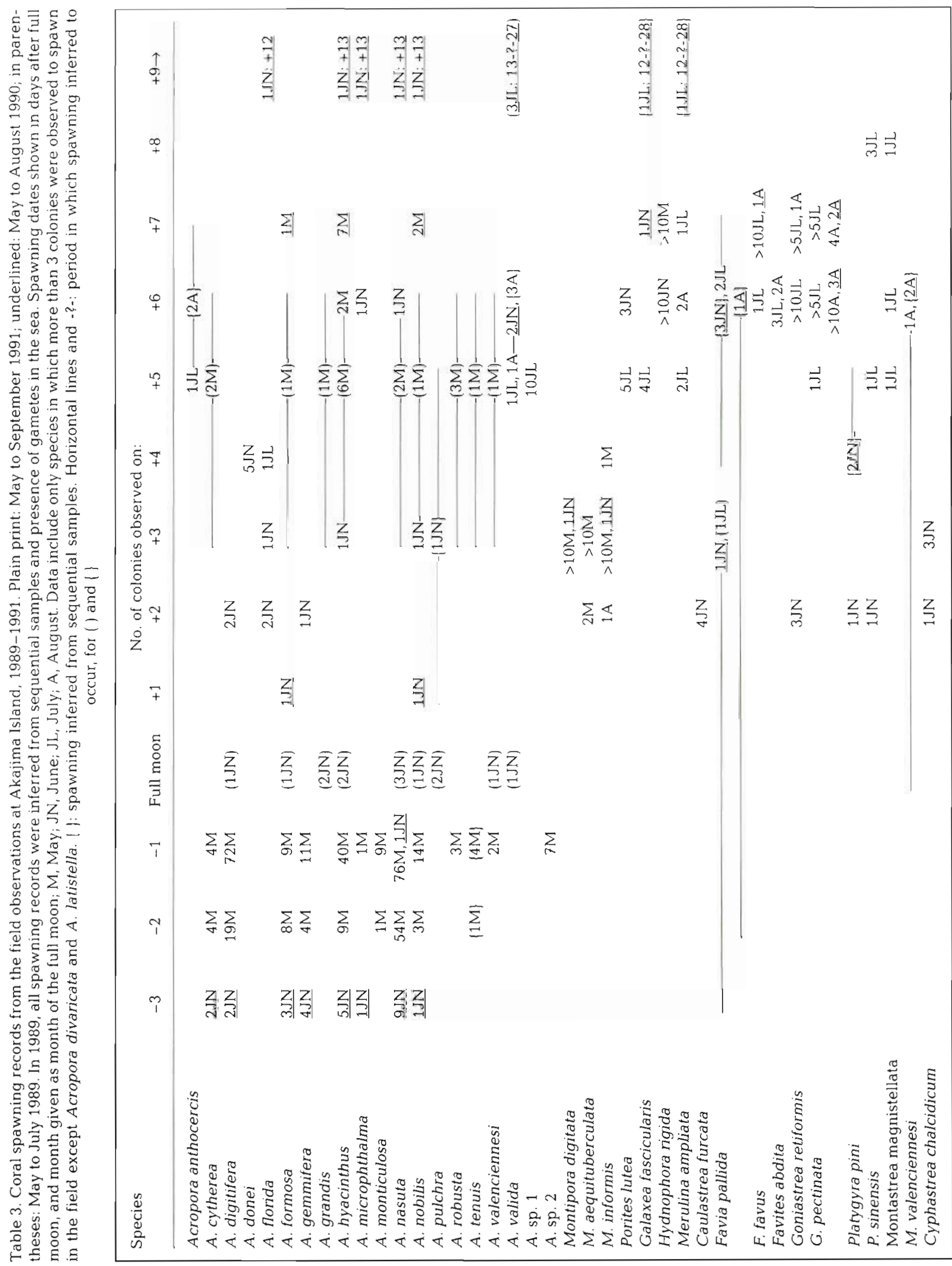




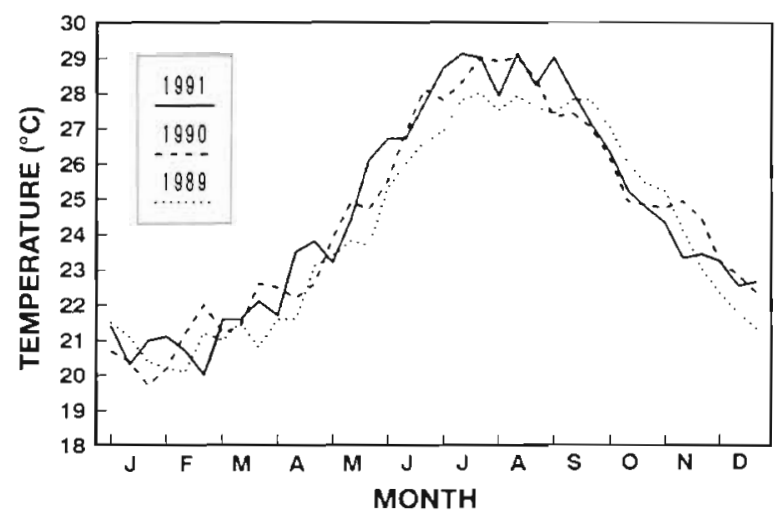

Fig. 4. Annual fluctuation of the tri-monthly mean of surface seawater temperature at Site 5, 1989-1991

perature peaks were 1 to $2 \mathrm{~h}$ later than those on the upper reef slope. Synchronous spawning took place about 11 to $12 \mathrm{~h}$ after the first peak of temperature on each day (Fig. 7). In contrast, the temperature rise on 26 and 27 May was also recorded at the outer reef flat of Site 2, but it was less sharp than that of the outer reef flat of Site 1 (Fig. 7). The peaks of temperature occurred 5 to $6 \mathrm{~h}$ later than that of Site 1. Synchronous spawning there took place only once, about $6.5 \mathrm{~h}$ after the peak of temperature on 27 May (Fig. 7).

\section{DISCUSSION}

\section{Species observed to spawn}

Previously, spawning of 26 species from 11 genera and 6 families of scleractinian corals had been reported in Okinawa, Japan (Heyward et al. 1987, Richmond \& Hunter 1990). The present study adds 4 families, 15 genera and 63 species to the spawning records for corals in Japan. Sixty-six of the 85 species studied have been observed to spawn on the Great Barrier Reef (Harrison et al. 1984, Willis et al. 1985, Babcock et al. 1986, Richmond \& Hunter 1990). Both the sexual characteristics (hermaphroditism or gonochorism) and the mode of reproduction (brooding or broadcast spawning) are the same for these species at Akajima and the Great Barrier Reef, as well as in the Central Pacific and the Red Sea (Harrison \& Wallace 1990. Richmond \& Hunter 1990).

\section{Synchrony, seasonality, periodicity and timing of spawning}

The spawning period of the corals in Akajima extended over $5 \mathrm{mo}$. In many species, spawning was recorded over 2 to $3 \mathrm{mo}$, indicating that the synchrony

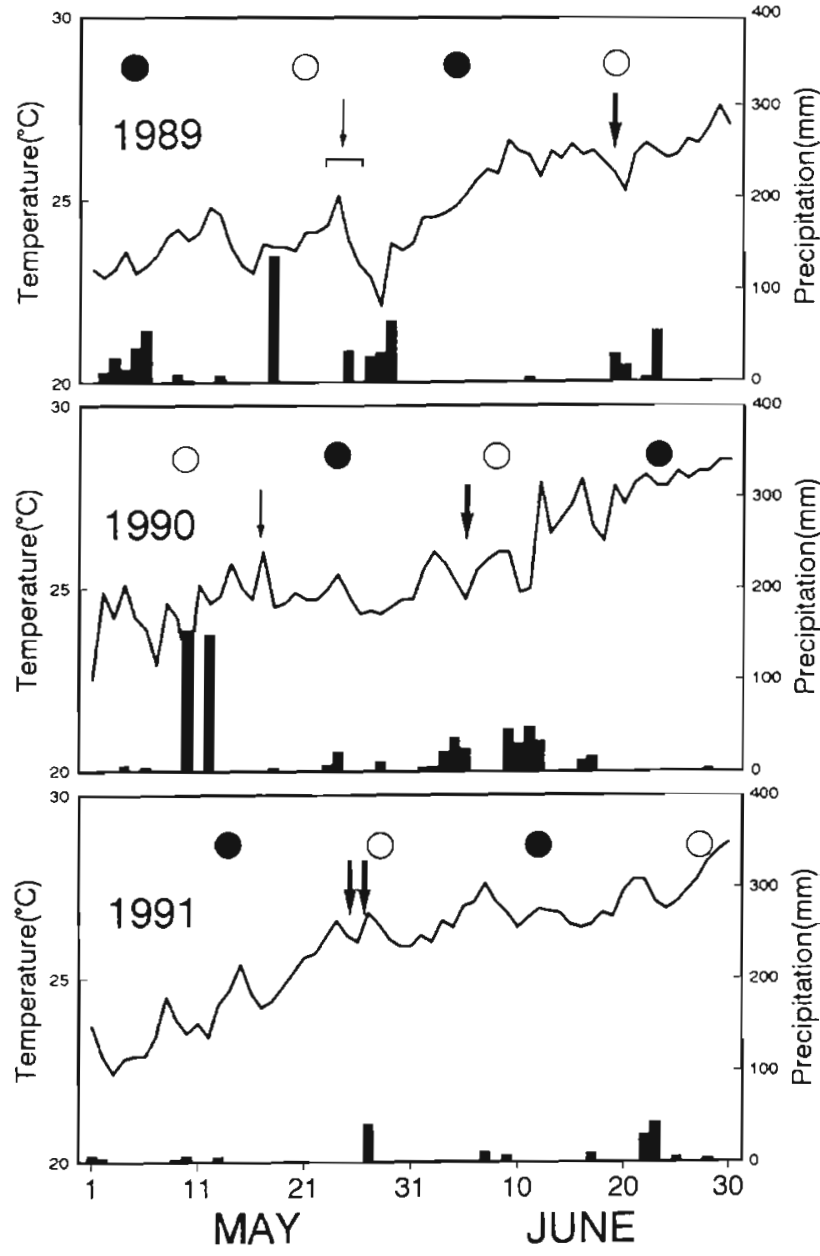

Fig. 5. Daily fluctuation of surface seawater temperature at Site 5 (lines) and daily precipitation in the Kerama Islands, May and June, 1989-1991 Open circles: full moon; solid circles: new moon. Arrows indicate observed dates of spawning of Acropora spp. Size of arrows shows the relative scale of mass spawning

of spawning in Akajima is less focused than that observed on the Great Barrier Reef where marked spawnings are observed for 3 to 4 nights over 1 or 2 mo (Willis et al. 1985, Babcock et al. 1986). However, the spawnings of Acropora spp. showed marked synchrony both within and between species in May and/or June in Akajima, and these spawnings can be considered to be 'mass spawning' events as defined by Willis et al. (1985).

Spawning seasonality in Akajima was similar to that found in the Red Sea (Shlesinger \& Loya 1985), but different from the situation on the Great Barrier Reef where mass spawning occurs after the spring temperature rise when the temperature is well below the summer maximum (Babcock et al. 1985). In contrast, Simpson (1986) found that mass spawning in the Dampier Archipelago in Western Australia occurs after 

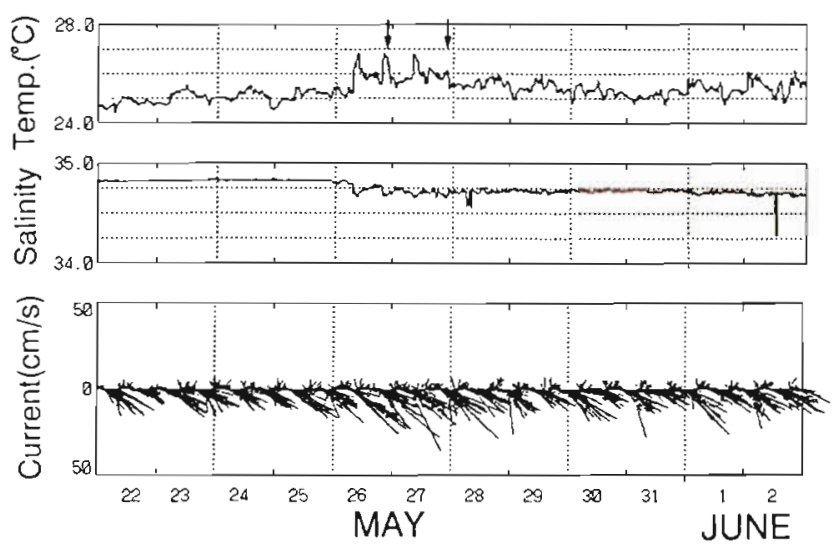

Fig. 6. Fluctuation of seawater temperature, salinity and current vector at the upper reef slope of Site 1 from 22 May to 2 June 1991. Arrows indicate mass spawning of Acropora species

a period of high, relatively constant temperature. This is also different from the situation on the Great Barrier Reef despite both regions experiencing similar seasonal temperature regimes.

Concerning these differences in seasonality, Harrison \& Wallace (1990) suggested that ultimate factors are exerting selective pressure on the timing of mass spawning events in each region. This hypothesis may be applicable to the situation at Akajima. At this island, the seawater temperature does not rise beyond $30^{\circ} \mathrm{C}$ throughout the year (Fig. 4), as it does in the Red Sea (Rinkevich \& Loya 1979). On the Great Barrier Reef and Dampier Archipelago, however, the tempera-
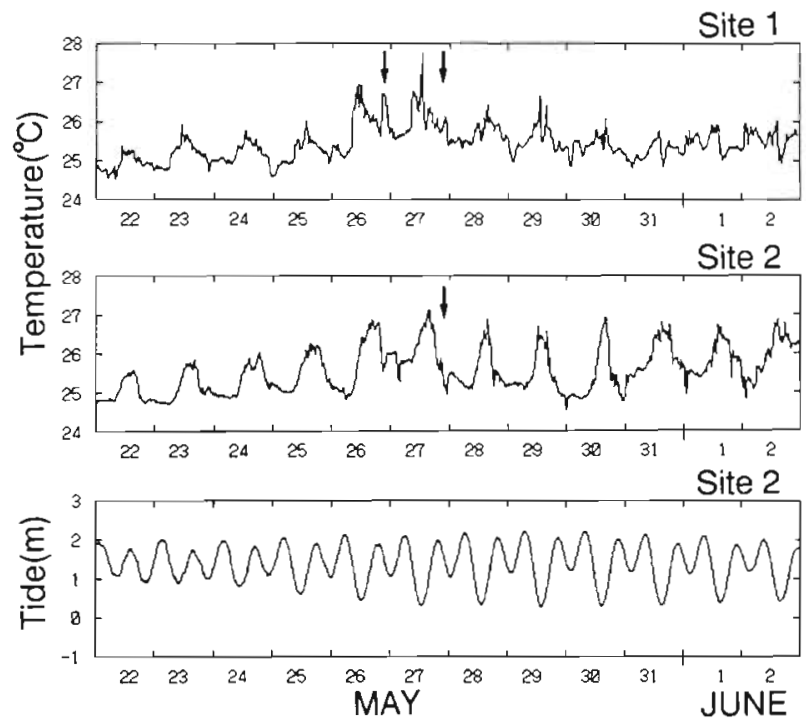

Fig. 7. Fluctuation of seawater temperature at the outer reef flat of Sites 1 \& 2, and tidal records at Site 2 from 22 May to 2 June 1991. Arrows indicate mass spawning of Acropora species ture sometimes rises above $30^{\circ} \mathrm{C}$ for about 2 mo in midsummer (Simpson 1985, Babcock et al. 1986). It is possible that the smaller range of sea temperatures at Akajima and the Red Sea provides a greater time period during which sea temperature is appropriate for successful reproduction, therefore coral spawning would be less synchronized in those regions compared with the Great Barrier Reef and Dampier Archipelago.

Some degree of lunar periodicity may also exert influence on the reproductive behavior of corals in Akajima. Although the Acropora species showed a wide variation of spawning activity in relation to the lunar phase, the spawning dates were mostly restricted to the period from the $3 \mathrm{rd}$ night before to the 7 th night after the full moon. The relationship between the spawning date and lunar phase was apparently weaker than that observed on the Great Barrier Reef where most coral spawning takes place only during a few nights (Babcock et al. 1986). However, some of the non-Acropora species showed a close relationship of spawning date to lunar phase, e.g. Favia favus, Goniastrea pectinata, G. retiformis, Montipora digitata and Porites lutea (Table 3).

The relationship between spawning and tidal phase was not consistent in Akajima, as most Acropora species spawned sporadically during an 11 night period, both before and after high tide and during both neap and spring tide periods. Babcock et al. (1986) reported that mass spawnings on the Great Barrier Reef are associated with low tide at neap tide, and suggested that low water volume and low water motion may enhance fertilization by increasing gamete concentration. In contrast, most of the spawning in Akajima occurred around high tide, suggesting that dispersal of gametes rather than fertilization might be an important factor controlling spawning time.

The spawning time at Akajima was generally restricted to the period from sunset to midnight, and agreed with reports from the Great Barrier Reef, Red Sea, Caribbean and Okinawa (Harrison et al. 1984. Shlesinger \& Loya 1985, Babcock et al. 1986, Szmant 1986, Heyward et al. 1987). This suggests that the spawning is induced by a specific dark period, and final synchronization and timing of spawning are controlled by photoperiod (Harrison et al. 1984, Babcock et al. 1986, Harrison \& Wallace 1990).

\section{Mass spawning of Acropora}

Although mass coral spawning was recorded on a number of occasions at Akajima, it occurred for only 1 or 2 nights in each event, indicating the existence of a certain cue to synchronize their spawning. For instance, in 1991, mass spawning occurred over 2 nights on 26 and 
27 May at Site 1, whereas it occurred on 27 May only at Site 2. Hermaphroditic corals usually release their eggs and sperm together as a spherical bundle. Wallace (1985) found egg-sperm bundles in the polyp cavities of Acropora loripes $4 \mathrm{~h}$ before the spawning commenced, and she considered that in Acropora species this bundle is formed some hours before spawning. The 1 night delay of spawning at Site 2 may have been caused by missing the time of bundle formation due to later rise of temperature at Site 2 as a stimulus.

The mass coral spawning at Akajima appears to be restricted to a certain period which is determined by the lunar phase, but lunar phase of mass spawning was not consistent between years and months (Fig. 2). Jokiel et al. (1985) and Hunter (1988) demonstrated that lunar illumination acts as a proximate controlling factor of timing of planula release or spawning of some coral species belonging to other genera than Acropora. However, for Acropora in Akajima, it is unlikely that the lunar phase acts as an absolute fine tuner for particular night(s) of mass spawning. Under natural conditions, other factors, e.g. such exogenous stimuli as marked changes in temperature, salinity and current velocity, may also act as the triggers.

We speculate that the mass spawning of Acropora in Akajima involves the following processes. Firstly, the breeding season is probably determined by the seasonal change in sea temperature regimes. Seasonal changes in day length could also regulate reproduction (Harrison \& Wallace 1990). Secondly, the corals may have a preparatory mechanism which determines the spawning date depending on the lunar cycle. As mentioned by Willis et al. (1985) and Babcock et al. (1986), the lunar cycle may act as a Zeitgeber to entrain spawning to occur during the appropriate lunar phase following the maturation of gametes. Thirdly, the corals may become sensitive to exogenous stimuli such as temperature when their gametes reached maturity. When stimulation is adequate, spawning may take place even before the full moon, but when there are no such stimuli, the corals will spawn on several nights after the full moon. There might also be participation of something like a chemical signal which acts as a cue spreading successively to increase spawning synchrony. Rigorous experimental studies are needed to determine whether these factors act independently or interactively as ultimate or proximate factors to determine the timing of coral spawning. How physical conditions that cue the initiation of gamete release differ among locations, and how populations at different locations react to them, should also be examined in detail to increase our understanding of coral spawning patterns.
Acknowledgements. We thank the following persons: C. C. Wallace and J. E. N. Veron for identification of corals; $T$ Ishimaru for providing comments on the environmental data; K. Yokol for supplying spawning data of Porites lutea in 1991; W. Wang, S. Ohike, A. Fujinaga and M. Hashimoto for assistance with observations. Valuable comments on the manuscript by R. H. Richmond are also acknowledged. P. Harrison and A. Heyward thank the Establishment of Tropical Marine Ecological Research for providing research funds at the Akajima Marine Science Laboratory in 1989, which enabled this study to be begun.

\section{LITERATURE CITED}

Babcock, R. C., Bull, G. D., Harrison, P. L., Heyward, A. J., Oliver, J. K., Wallace, C. C., Willis, B. L. (1986). Synchronous spawning of 105 scleractinian coral species on the Great Barrier Reef. Mar. Biol, 90: 379-394

Harrison, P. L. (1988). Pseudo-gynodioecy: an unusual breeding system in the scleractinian corals Galaxea fascicularis. Proc. 6th int coral Reef Symp. 2: 699-705

Harrison, P. L., Babcock, R. C., Bull, G. D., Oliver, J. K., Wallace, C. C., Willis, B. L. (1984). Mass spawning in tropical reef corals. Science 223: 1186-1189

Harrison, P. L. Wallace, C. C. (1990). Reproduction, dispersal and recruitment of scleractinian corals. In: Dubinsky, $Z$. (ed.) Ecosystems of the world, Vol. 25, Coral reefs. Elsevier Science Publishers, Amsterdam, p. 133-207

Heyward, A., Yamazato, K., Yeemin, T., Minei, M. (1987). Sexual reproduction of corals in Okinawa. Galaxea 6 : $331-343$

Hunter, C. L. (1988). Environmental cues controlling spawning in two Hawailan corals, Montipora verrucosa and M. dilatata. Proc. 6th int. coral Reef Symp. 2: 727-732

Jokiel, P. L., Ito, R. Y., Liu, P. M. (1985). Night irradiance and synchronization of lunar release of planula larvae in the reef coral Pocillopora damicornis. Mar. Biol. 88: 167-174

Oliver, J. K., Babcock, R. C., Harrison, P. L., Willis, B. L. (1988). Geographic extent of mass coral spawning: clues to ultimate causal factors. Proc. 6th int. coral Reef Symp. 2: $803-810$

Richmond, R. H., Hunter, C. L. (1990). Reproduction and recruitment of corals: comparisons among the Caribbean, the Tropical Pacific, and the Red Sea. Mar. Ecol. Prog. Ser. 60: $185-203$

Rinkevich, B., Loya, Y (1979). The reproduction of the Red Sea coral Stylophora pistillata. I. Synchronisation in breeding and seasonality of planulae shedding. Mar. Ecol. Prog. Ser. 1: 145-152

Shlesinger, Y., Loya, Y. (1985). Coral community reproductive patterns: Red Sea versus the Great Barrier Reef. Science 228: $1333-1335$

Simpson, C. J. (1985). Mass spawning of scleractinian corals in the Dampier archipelago and the implications for management of coral reefs in Western Australia. West. Aust. Dep. Conserv. Environ. Bull. 244

Szmant, A. M. (1986). Reproductive ecology of Caribbean reef corals. Coral Reefs 5: 43-54

Wallace, C. C. (1985). Reproduction, recruitment and fragmentation in nine sympatric species of the coral genus Acropora. Mar. Biol. 88: 217-233

Willis, B. L., Babcock, R. C., Harrison, P. L., Oliver, J. K. (1985). Patterns in the mass spawning of corals on the Great Barrier Reef from 1981 to 1984. Proc. 5th int. coral Reef Congr. 4: 343-348

Manuscript first received: February 12, 1993

Revised version accepted: August 12, 1993 